\title{
Improving the Quality of Learning through Teacher's Guidance
}

\author{
Fitriana \\ SD Negeri 15 Betung \\ Email: fitrianapurpurwanto@gmail.com \\ Edi Harapan \\ Universitas PGRI Palembang, Indonesia \\ e-mail: ehara205@gmail.com \\ Nila Kesumawati \\ Universitas PGRI Palembang, Indonesia \\ e-mail: nilakesumawati@yahoo.com \\ Article History: Received on 5 November 2021, Revised on 15 January 2022 \\ Published on 24 January 2022
}

\begin{abstract}
This study identified teacher teaching development as a means of improving the quality of learning at SD Negeri 15 Betung. The school served as the site for this study. This is a qualitative in which data is gathered through interviews, observation, and documentation. According to the results, teacher teaching development as an effort to improve the quality of learning at SD Negeri 15 Betung could be said good the ability of teachers to manage classes in terms of lesson plan and learning implementation; and the ability of the teacher to manage classes in terms of the teacher's activities opening and closing lessons. The teacher's competence handle the class means the teacher's activities in delivering reinforcement.
\end{abstract}

Keywords: Quality Improvement, Learning, Teacher's Guidance

\section{A. Introduction}

One of the most crucial aspects of school is the instructor. The quality standards of instructors have a big impact on the excellent and bad quality of education. As a result, instructors must increase their competence in accordance with Law No. 14 of 2005 concerning Teachers and Lecturers. Teachers must possess four competencies: pedagogical, personality, professional, and social competence. Then there's the question of whether Indonesian teachers' competency criteria fulfill the four competencies listed above The actual actions must be taken to increase the quality and ability of instructors. The Ministry of Education and Culture recognizes this and expects it by mapping Indonesian teacher competency requirements (Muningsih, 2015).

Various trainings have been conducted to increase teacher competency, including teaching training that is relevant to the times, such as the use of technology. The normative issue in the form of teacher certification as a guarantee of passing the competency test as a professional teacher emerges later in the context of carrying out the professional tasks of a teacher or educator. Even if it offers fresh optimism in terms of teacher welfare, it is also the result of educators' or instructors' fear and uncertainty (Nurkhotijah, 2016).

Teachers must be qualified in accordance with specified criteria. A certificate is evidence of quality according to specified requirements that guarantee someone may be called a 
Volume 2 (3) 2021

E-ISSN: 2723-6919 P-ISSN: 2746-0827

professional teacher. Obtaining a credential as a professional teacher requires passing the teacher competence test. The numerous teacher quality development programs essentially seek to increase teachers' talents and skills in planning, creating, implementing, and overseeing the learning process in order to promote the improvement of education quality in each school unit (Sumardin, 2016).

Classroom management is a component of education that is frequently the primary concern of prospective teachers, new teachers, and even veteran instructors who want their pupils to learn to the best of their abilities. The subject of classroom management is the formation of such expectations (Khotimah et al, 2020).

According to the Principal of the SD Negeri 15 Betung, the principal constantly offers direction to teachers who educate in order to improve the quality of learning. However, four civil servant instructors now hold educator certificates, whereas one civil servant teacher does not. Existing facilities at the SD Negeri 15 Betung are relatively restricted, such as the completeness of teaching aids as a learning resource, the books supporting instructors in providing learning, which are still deemed insufficient due to the availability of funding. Disciplines taught there are still non-linear, but because the learning material is for primary school pupils, coaching may still be provided. To ensure that the quality of learning runs smoothly, the teacher is urged to continue with higher and better education, especially to the master level, so that the information obtained may be implemented appropriately and, ultimately, can improve the quality of education at SD Negeri 15 Betung.

\section{B. Methods}

This study use qualitative research methodologies in order to acquire a thorough knowledge and interpretation of the significance of the occurrences in the area. The participants in the study were all teachers at the SD Negeri 15 Betung. Data were collected through interviews with teachers at the SD Negeri 15 Betung, Banyuasin Regency in terms of: 1) lesson planning, 2) learning implementation, 3) activities when the teacher delivered learning materials, 4) teachers delivered material varied learning, 5) the teacher's ability to ask questions, and 6) the provision of reinforcement (Sutrisno, 2011; Moleong, 2011; Sudaryono, 2009; Sukmadinata, 2015).

\section{Results and Discussion}

According to the results, teacher teaching development as an effort to improve the quality of learning at SD Negeri 15 Betung could be said good the ability of teachers to manage classes in terms of lesson plan and learning implementation; and the ability of the teacher to manage classes in terms of the teacher's activities opening and closing lessons. The teacher's competence to handle the class in terms of the teacher's activities in delivering reinforcement.

According to the findings of the researcher's interview with the principal, he has provided instructions to the instructors in creating learning devices that must refer to the set curriculum. The principal has directed teachers to carry out learning activities in accordance with the themes that have been arranged, but there are also teachers who carry out learning activities that are not in accordance with the theme, especially given the state of the Covid-19 pandemic. The material that must be conveyed by the teacher refers to Semester programs, and annual programs must be carried out according to the timetable. The principal always checks or 
Volume 2 (3) 2021

E-ISSN: 2723-6919 P-ISSN: 2746-0827

evaluates the learning outcomes delivered by the teacher during the middle of the semester in order to see the student learning outcomes that have been implemented; 4) The principal has instructed teachers to follow up on the learning outcomes that have been delivered, especially to students who have not reached the set score, and instructed teachers to provide additional lessons (remedial), especially to students whose grades are low have not yet reached the set score (Mayasari et al, 2021; Nuryani et al, 2021; Lydia et al, 2021).

At the mid-semester meeting, the principal directed and advised the instructors to pay attention while also providing help to pupils who are having difficulty studying. If there are pupils who are truant, the principal has given the instructor instructions to advise them not to be truant any longer. The school he runs already has appropriate teaching aids, but some of them have been damaged, therefore the teachers use these teaching aids in turn when delivering learning materials (Gangsar, 2012; Feri, 2017). As a leader, he always seeks to send instructors to engage in training activities, especially new teachers, so that their capacity to manage classrooms grows (Sudrajat, 2018).

The government has made efforts to improve teacher quality in a variety of ways, including providing block grants to schools as stimulus funds to implement teacher professional development programs, forming subject teacher associations, establishing teacher scientific forum organizations, and publishing scientific journals. For instructors and teachers to use the Subject Teacher Consultation program, which has previously been available in practically every district/city. The numerous teacher quality development programs essentially seek to increase teachers' talents and skills in planning, creating, implementing, and overseeing the learning process in order to promote the improvement of education quality in each school unit (Sumardin, 2016).

Classroom management is a component of education that is frequently the primary concern of prospective teachers, new teachers, and even veteran instructors who want their pupils to learn to the best of their abilities. The subject of classroom management is the formation of such expectations. Djamarah and Zain state that (2010). Classroom management is a complicated behavioral challenge that instructors utilize to create and maintain classroom settings that allow students to efficiently fulfill their teaching goals while also allowing them to learn (Kristiawan et al, 2017) According to the results on teacher teaching coaching as one of the efforts to improve the quality of learning at SD Negeri 15 Betung, it is supported by relevant research, including research conducted by Mardalena et al, (2020), where the findings explain first, that there is a significant influence. Academic supervision has a substantial influence on the performance of Tanjung Raja District State Senior Secondary School instructors. Second, there is a considerable influence of teacher professional competence on the performance of Tanjung Raja District State Senior High School instructors. Third, academic supervision and teacher professional competence have a major impact on the performance of Tanjung Raja District State Senior High School instructors. Whereas this study investigates instructors' competency in relation to how they educate, which ultimately leads to the quality of learning (Hidayat, 2012).

According to Marulloh (2015) the average score of teacher competence in classroom management increased. The study shows that clinical supervision can help teachers enhance their classroom management skills. Tursinawati (2016) explains that: 1) almost all instructors manage the class very effectively, but there are some teachers who are not excellent at managing the class, which can be noticed in helping students concentrate attention throughout 
Volume 2 (3) 2021

E-ISSN: 2723-6919 P-ISSN: 2746-0827

the learning process; 2) Learning process limits imposed by teachers; children with special needs have different understandings than other pupils. As a result, it is difficult for ABK to accept learning since some learnings are not appropriate for their capacities. Based on Tursinawati's research, it can be anticipated that this research can boost existing research and help researchers examine teacher teaching development in an effort to improve the quality of learning at SD Negeri 15 Betung (Warsono, 2016; Kenneth et al, 2015).

\section{Conclusion}

Based on the result, it is possible to infer that teacher teaching development as an endeavor to improve the quality of learning at SD Negeri 15 Betung is effective.

\section{E. Acknowledgement}

Thank to the Principal of SD Negeri 15 Betung, Rector Universitas PGRI Palembang, Director of Graduate Program and friends of graduate program educational management Universitas PGRI Palembang who have supported us to do this project.

\section{References}

Djamarah., Bahri, S., \& Zain, A. (2010). Strategi Belajar Mengajar [Teaching and Learning Strategy]. Jakarta: Rineka Cipta.

Feri, N. (2017). Manajemen Pembelajaran Guru Pada SD Negeri 1 Pelukan Pidie Kabupaten Pidie [Teacher Learning Management at SD Negeri 1 Hug Pidie, Pidie Regency]. Jurnal Manajer Pendidikan, 9(5), 699-703.

Gangsar, F. U. (2012). Kemampuan Guru Mengelola Kelas 4 dan 5 SD Negeri Pandeyan Umbulharjo Yogyakarta [Teacher Ability to Manage Grades 4 and 5 SD Negeri Pandeyan Umbulharjo Yogyakarta]. Jurnal Manajemen Pendidikan, 2(2), 182-197.

Sutrisno, H. (2011). Penelitian Kualitatif [Qualitative Research]. Bandung: Alfabeta.

Hidayat, M. T. (2012). Kemampuan Guru dalam Mengelola Kelas dan Pengaruhnya Terhadap Prestasi Belajar Siswa Pada Mata Pelajaran IPS di MTs NU Astanajapura Kabupaten Cirebon [Teacher's Ability in Managing Classrooms and Its Influence on Student Achievement in Social Studies Subjects at MTs NU Astanajapura Cirebon Regency]. Jurnal Manajemen Pendidikan, 3(2), 216-231.

Lydia, L., Fitria, H., \& Puspita, Y. (2021). Policy Implementation of Educational Quality Improvement Based on National Education Standard. Journal of Social Work and Science Education, 1(3), 221-233. https://doi.org/10.52690/jswse.v1i3.109

Kenneth D. M. (2015). Effective Instruction Strategies. New Delhi. Sage Publications, Inc.

Khotimah, H. Harapan, E. Kesumawati, N. (2020). Kualitas Guru Mengajar Sebagai Salah Satu Upaya Meningkatkan Status Akreditasi Sekolah [Quality of Teaching Teachers as an Effort to Improve School Accreditation Status]. JMKSP (Jurnal Manajemen, Kepemimpinan, dan Supervisi Pendidikan), 6(1), 124:131. 
Kristiawan, M., Safitri, D., \& Lestari, R. (2017). Manajemen Pendidikan [Education Management]. Yogyakarta: Deepublish.

Law No. 14 of 2005 concerning Teachers and Lecturers

Mardalena., Arafat, Y., \& Fitria, H. (2020). Pengaruh Supervisi Akademik dan Kompetensi Profesional Guru terhadap Kinerja Guru di Sekolah Menengah Atas Negeri di Kecamatan Tanjung Raja [The Effect of Academic Supervision and Teacher Professional Competence on Teacher Performance in Public High Schools in Tanjung Raja District]. Jurnal Manajemen Pendidikan, 9(1), 104-114.

Marulloh. (2015). Peningkatan Kemampuan Guru dalam Mengelola Kelas Melalui Supervisi Klinis di SMAN 10 Bengkulu [Improving Teacher Ability in Managing Classes Through Clinical Supervision at SMAN 10 Bengkulu]. Jurnal Manajemen Pendidikan, 3(1), 282197.

Mayasari, I., Arafat, Y., \& Setiawan, A. A. (2021). The Effect of Principal Leadership and Teacher Performance Toward Student Achievement. Journal of Social Work and Science Education, 2(2), 188-197. https://doi.org/10.52690/jswse.v2i2.249

Moleong, L. (2011). Metodologi Penelitian Kualitatif [Qualitative Research Methodology]. Bandung: Remaja Rosdakarya.

Muningsih. (2015). Manajemen Kelas Guru Sekolah Dasar (Studi Analisis Pembelajaran Pada Siswa SDN 02 Curup Timur) [Class Management of Elementary School Teachers (Learning Analysis Study on Students of SDN 02 Curup Timur)]. Jurnal Manajer Pendidikan, 9(5), 699-703.

Nurkhotijah, F. 2016. Keterampilan Guru dalam Pengelolaan Kelas Pada Pembelajaran Tematik Kelas V Ali Bin Abi Thalib di MIN Purwokerto [Teacher Skills in Classroom Management in Ali Bin Abi Talib's Fifth Grade Thematic Learning at MIN Purwokerto]. Jurnal Manajemen Pendidikan, 2(2), 112-127.

Nuryani, N., Harapan, E., \& Wardiah, D. (2021). Principal's Managerial in Improving the Quality of Education in Primary School. Journal of Social Work and Science Education, 2(1), 52-59. https://doi.org/10.52690/jswse.v2i1.205

Sudaryono. (2009). Metode Penelitian Kualitatif [Qualitative Research Methods]. Bandung: Remaja Rosdakarya.

Sudrajat. (2018). Manajemen Kinerja Guru Sekolah Dasar [Elementary School Teacher Performance Management]. Jurnal Administrasi Pendidikan, XXV(1) 104-119.

Sukmadinata, N. S. (2015). Metode Penelitian Pendidikan [Educational Research Methods]. Bandung: Remaja Rosdakarya. 
Journal of Social Work and Science Education

Volume 2 (3) 2021

E-ISSN: 2723-6919 P-ISSN: 2746-0827

Sumardin. (2016). Pengembangan Profesionalisme Guru Berbasis MGMP Model dan Implementasinya [Teacher Professionalism Development Based on MGMP Model and Its Implementation]. Yogyakarta: Budi Utama.

Tursinawati. (2016). Kemampuan Guru dalam Mengelola Kelas Untuk Siswa yang Berkebutuhan Khusus di SDN 16 Banda Aceh [Teacher's Ability in Managing Classes for Students with Special Needs at SDN 16 Banda Aceh]. Jurnal Manajemen Pendidikan, $3(1), 252-267$.

Warsono. (2016). Pengelolaan Kelas dalam Meningkatkan Belajar Siswa [Classroom Management in Improving Student Learning]. Jurnal Manajemen dan Administrasi Pendidikan, 2(2), 102-115. 